\title{
Differences between oral cancer and cancers of the pharynx and larynx on a molecular level
}

\author{
KIYOTO SHIGA ${ }^{1}$, TAKENORI OGAWA ${ }^{2}$, KATSUNORI KATAGIRI ${ }^{1}$, FUMIAKI YOSHIDA ${ }^{2}$, \\ MASARU TATEDA ${ }^{2}$, KAZUTO MATSUURA ${ }^{3}$ and TOSHIMITSU KOBAYASHI ${ }^{2}$ \\ ${ }^{1}$ Department of Otolaryngology-Head and Neck Surgery, Iwate Medical University Hospital, Morioka, Iwate; \\ ${ }^{2}$ Department of Otolaryngology-Head and Neck Surgery, Tohoku University Hospital, Sendai, Miyagi; \\ ${ }^{3}$ Department of Head and Neck Surgery, Miyagi Cancer Center Hospital, Natori, Miyagi, Japan
}

Received July 6, 2011; Accepted October 11, 2011

DOI: $10.3892 / \mathrm{ol} .2011 .451$

\begin{abstract}
In order to elucidate differences between oral cancers and cancers of the pharynx and larynx, we investigated the genetic and epigenetic changes in these tumors using molecular biology methods. Methylation of the promoter region of the p16 tumor suppressor gene was examined using methylation-specific polymerase chain reaction in specimens from 47 oral, 39 pharyngeal and 35 laryngeal squamous cell carcinomas. These specimens were also characterized for allelic loss of certain areas of the genome, i.e., 3p22, 9p21 and 17p13 (TP53). The frequency of methylation of the promoter region of the p16 gene in tongue cancers $(35.3 \%)$ was significantly higher than in pharyngeal $(12.8 \%)$ and laryngeal cancers $(11.4 \%)(\mathrm{p}=0.046$ and $\mathrm{p}=0.039$, respectively). The frequency of methylation in tumors of female patients $(47.1 \%)$ was significantly higher compared to tumors of male patients $(15.4 \%)(\mathrm{p}=0.0067)$. In contrast, the frequency of the loss of heterozygosity $(\mathrm{LOH})$ at $3 \mathrm{p} 21$ in pharyngeal cancers $(66.7 \%)$ was significantly higher than in oral cancers $(20.0 \%)(\mathrm{p}=0.0006)$. The frequencies of $\mathrm{LOH}$ at $17 \mathrm{p} 13$ in pharyngeal $(71.0 \%)$ and laryngeal cancers $(73.1 \%)$ were also significantly higher than in oral cancers $(36.1 \%)(\mathrm{p}=0.009$ and $\mathrm{p}=0.009$, respectively). Our results indicate that there are marked differences in the frequencies of the hypermethylation of genes and allelic loss between oral cancers and cancer of the pharynx and larynx. Although all of these tumors were diagnosed as squamous cell carcinomas, the process of carcinogenesis may be different in tumors located in various parts of the head and neck. Loss of function of tumor suppressor genes by allelic loss gives rise to tumors in the pharynx and larynx, while loss of function due to methylation of the promoter regions of those genes is related to carcinogenesis in the oral cavity.
\end{abstract}

Correspondence to: Professor Kiyoto Shiga, Department of Otolaryngology-Head and Neck Surgery, Iwate Medical University Hospital, 19-1 Uchimaru, Morioka, Iwate 020-8505, Japan

E-mail: kshiga44@hotmail.co.jp

Key words: head and neck cancers, loss of heterozygosity, DNA methylation, location of the tumor, gender

\section{Introduction}

Head and neck squamous cell carcinomas (HNSCCs) manifest various clinical behaviors according to their area of origin, i.e., from various parts of the head and neck mucosa. However, genetic and epigenetic factors involved in the carcinogenesis of HNSCC in various tissues have yet to be thoroughly studied and evaluated. Although there have been numerous studies on the hypermethylation of the promoter regions of tumor suppressor genes, particularly p16 (1-9), differences in the frequencies of methylation among the cancer sites in the head and neck region have yet to be elucidated, partly due to the low number of samples. However, we have previously pointed out differences in the frequencies of allelic loss of certain areas of the genome between oral cancers and cancers of the pharynx and larynx (10).

To elucidate the differences between oral cancer and cancers of the pharynx and larynx, we investigated the genetic and epigenetic changes in these tumors using molecular biology methods. We analyzed the hypermethylation of the promoter region of the p16 tumor suppressor gene as an epigenetic change. We also examined allelic loss of certain areas of the genome, i.e., 3p21, 9p21 and 17p13 (TP53) as genetic changes. Comparing the results of these two approaches reveals novel findings regarding the differences between oral cancer and cancers of the pharynx and larynx.

\section{Materials and methods}

Patients and tissue specimens. Primary tumors were removed surgically or obtained as biopsies prior to treatment during the period between May 1994 and November 2000, following an approved protocol at the Miyagi Cancer Center. The clinical features of the patients are summarized in Table I.

This study was approved by the Institutional Review Boards of Tohoku University and the Miyagi Cancer Center. Surgical specimens were obtained under informed consent, and written informed consent was obtained from all patients.

DNA preparation. Genomic DNA was extracted from the frozen tissue samples using proteinase $\mathrm{K}$ digestion and phenol extraction according to standard methods $(11,12)$. 
Table I. Clinical features of the patients and tumor location.

\begin{tabular}{|c|c|c|c|c|c|c|c|c|c|c|}
\hline & \multicolumn{5}{|c|}{ Oral cavity } & \multicolumn{3}{|c|}{ Pharynx } & \multirow[b]{2}{*}{ Larynx } & \multirow[b]{2}{*}{ P-value } \\
\hline & Overall & Tongue & FOM & $\mathrm{BM}$ & Gingiva & Overall & Meso & Нyро & & \\
\hline \multicolumn{11}{|l|}{ Age } \\
\hline $45>$ & 6 & 6 & 0 & 0 & 0 & 0 & 0 & 0 & 2 & 0.021 (OC vs. P) \\
\hline $45<$ & 41 & 28 & 6 & 4 & 3 & 39 & 14 & 25 & 33 & \\
\hline \multicolumn{11}{|l|}{ Gender } \\
\hline Female & 14 & 9 & 0 & 4 & 1 & 2 & 0 & 1 & 1 & 0.0034 (OC vs. P) \\
\hline Male & 33 & 25 & 6 & 0 & 2 & 37 & 14 & 24 & 34 & 0.0018 (OC vs. L) \\
\hline \multicolumn{11}{|l|}{ Tumor size $\mathrm{e}^{\mathrm{a}, \mathrm{b}}$} \\
\hline $\mathrm{T} 1$ & 8 & 6 & 2 & 0 & 0 & 1 & 0 & 1 & 8 & NS \\
\hline $\mathrm{T} 2$ & 20 & 14 & 3 & 2 & 1 & 19 & 4 & 15 & 14 & \\
\hline $\mathrm{T} 3$ & 13 & 10 & 1 & 2 & 0 & 9 & 6 & 3 & 6 & \\
\hline $\mathrm{T} 4$ & 3 & 1 & 0 & 0 & 2 & 9 & 4 & 5 & 6 & \\
\hline $\begin{array}{l}\text { Lymph node } \\
\text { involvement }^{\mathrm{a}}\end{array}$ & & & & & & & & & & N0 vs. others \\
\hline N0 & 28 & 20 & 4 & 2 & 2 & 10 & 2 & 8 & 29 & 0.0016 (OC vs. P) \\
\hline N1 & 8 & 6 & 1 & 1 & 0 & 7 & 3 & 4 & 1 & $<0.0001(\mathrm{P}$ vs. L) \\
\hline $\mathrm{N} 2$ & 10 & 7 & 1 & 1 & 1 & 20 & 9 & 11 & 4 & \\
\hline N3 & 1 & 1 & 0 & 0 & 0 & 2 & 0 & 2 & 1 & \\
\hline Stage $^{\mathrm{a}}$ & & & & & & & & & & I and II vs. III and IV \\
\hline I & 8 & 7 & 1 & 0 & 0 & 1 & 0 & 1 & 7 & 0.0004 (OC vs. P) \\
\hline II & 17 & 12 & 3 & 1 & 1 & 5 & 0 & 5 & 11 & 0.0009 (P vs. L) \\
\hline III & 10 & 7 & 1 & 2 & 0 & 9 & 4 & 5 & 6 & \\
\hline IV & 12 & 8 & 1 & 1 & 2 & 24 & 10 & 14 & 11 & \\
\hline Total & 47 & 34 & 6 & 4 & 3 & 39 & 14 & 25 & 35 & \\
\hline
\end{tabular}

Patients who had recurrent lymph node metastasis were omitted from this classification. Meso, mesopharyngeal; Hypo, hypopharyngeal; NS, not significant. FOM, floor of mouth; BM, buccal mucosa; OC, oral cavity; P, pharynx; L, larynx.

Detection of hypermethylation in the pl6 gene promoter region. The detection of gene hypermethylation was performed using sodium bisulfite for DNA modification followed by methylation-specific polymerase chain reaction (MSP). DNA modification was performed using a CpGenome DNA Modification Kit (Chemicon International, Temecula, CA, USA). The sequences of the primers used were as follows: p16U forward, 5'-TTATT AGAGGGTGGGGTGGATTGT-3' and reverse, 5'-CAACCCC AAACCACAACCATAA-3'; p16M forward, 5'-TTATTAGA GGGTGGGCGGATCGC-3' and reverse, 5'-GACCCCGAACC GCGACCGTAA-3'. The annealing temperatures of the PCR reactions for p16U and p16M were 60 and $69^{\circ} \mathrm{C}$, respectively. Purified PCR products were separated by electrophoresis on $3 \%$ agarose gels containing $1 \mathrm{mg} / \mathrm{ml}$ ethidium bromide.

Detection of allelic loss. The polymorphic markers, D3S1067, IFNA, D3S171 and TP53, were purchased from Invitrogen (Carlsbad, CA, USA) and each forward primer of those markers was labeled using $\left[\gamma^{32} \mathrm{p}\right] \mathrm{ATP}$ and polynucleotide kinase (Takara Shuzo, Kyoto, Japan). PCR was performed using a thermal cycler (Perkin-Elmer Cetus, Boston, MA, USA) for 36 cycles under optimal conditions, i.e., $1 \mathrm{~min}$ at $94^{\circ} \mathrm{C}, 1 \mathrm{~min}$ at $56^{\circ} \mathrm{C}$ and $1 \mathrm{~min}$ at $72^{\circ} \mathrm{C}$, except for the first denaturation, which was performed at $94^{\circ} \mathrm{C}$ for 5 min. Purified PCR products were separated by electrophoresis on $6 \%$ polyacrylamide gels containing $8.3 \mathrm{M}$ urea (10).

Statistical analysis. Statistical analyses of the data were performed using the $\chi^{2}$ test.

\section{Results}

Table I shows the clinicopathological features of the patients and their tumors. The ages of the patients with oral cancers were significantly lower than those with cancers of the pharynx and larynx. As for gender, the number of female patients was significantly higher among patients with oral cancer than those with cancers of the pharynx and larynx. Advanced stage (stage III and IV) patients were significantly higher in patients with cancers of the pharynx and larynx than those with oral cancer. This is due to the fact that lymph node metastases were significantly more frequent in patients with cancers of the pharynx and larynx than in those with oral cancer.

Hypermethylation of the promoter region of the p16 tumor suppressor gene was detected using the MSP method. We exam- 
Table II. Hypermethylation of the p16 promoter region, tumor location and gender.

\begin{tabular}{|c|c|c|c|c|}
\hline & Unmethylated & Methylated & Methylated (\%) & P-value \\
\hline Oral cancer & 32 & 15 & 31.9 & $0.047\left(\right.$ vs.HP) ${ }^{\mathrm{a}}$ \\
\hline Tongue & 22 & 12 & 35.3 & $0.046(\text { vs.P })^{\mathrm{b}}$ \\
\hline Floor of mouth & 6 & 0 & & \\
\hline Buccal mucosa & 1 & 3 & & \\
\hline Gingiva & 3 & 0 & & \\
\hline Pharyngeal cancer & 34 & 5 & 12.8 & \\
\hline Mesopharynx & 11 & 3 & 21.4 & \\
\hline Hypopharynx & 23 & 2 & 8.7 & $0.033(\text { vs. T) })^{\mathrm{c}}$ \\
\hline Laryngeal cancer & 31 & 4 & 11.4 & $0.039\left(\right.$ vs. T) ${ }^{\mathrm{d}}$ \\
\hline \multicolumn{5}{|l|}{ Gender } \\
\hline Female & 9 & 8 & 47.1 & 0.0067 \\
\hline Male & 88 & 16 & 15.4 & \\
\hline Total & 97 & 24 & 19.8 & \\
\hline
\end{tabular}

Significant differences were observed between ${ }^{\mathrm{a}}$ oral cancer (OC) and hypopharynx (HP), ${ }^{b}$ tongue (T) and pharyngeal cancer (P), ${ }^{\mathrm{c}} \mathrm{T}$ and $\mathrm{HP},{ }^{\mathrm{d}} \mathrm{T}$ and laryngeal cancer.

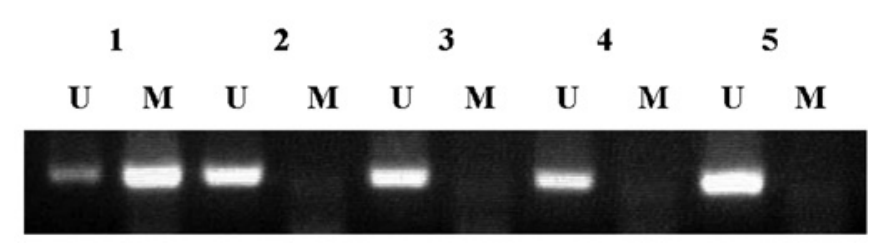

Figure 1. Hypermethylation of the p16 gene promoter region detected by the bisulfite-MSP method. Lane 1, tongue cancer (T2N0M0); lane 2, laryngeal cancer (T4NOM0); lane 3, cancer of the floor of the mouth (T2N0M0); lane 4, hypopharyngeal cancer (T2N2aM0); lane 5, hypopharyngeal cancer (T2N2aM0). U, unmethylated; M, methylated. The methylated band was observed only in tongue cancer (lane 1).

ined 47 oral cancers, 39 pharyngeal cancers and 35 laryngeal cancers. Representative results are shown in Fig. 1 and all results are summarized in Table II and Fig. 2. The frequencies of methylation of the promoter region of the p16 gene in oral and tongue cancers were 31.9 and $35.3 \%$, respectively. On the contrary, those of pharyngeal and laryngeal cancers were 12.8 and $11.4 \%$, respectively, and those of mesopharyngeal and hypopharyngeal cancers were 21.4 and $8.7 \%$, respectively. The frequency of methylation in oral cancers was significantly higher than in hypopharyngeal cancers $(\mathrm{p}=0.047)$. The frequency of methylation in tongue cancers was significantly higher than in pharyngeal, hypopharyngeal and laryngeal cancers $(p=0.046$, 0.033 and 0.039 , respectively). However, the frequency of methylation in tumors of female patients $(47.1 \%)$ was significantly higher than in tumors of male patients $(15.4 \%)(\mathrm{p}=0.0067)$.

Specimens of 47 oral, 39 pharyngeal and 35 laryngeal squamous cell carcinomas were characterized for allelic loss of certain areas of the genome, i.e., 3p22, 9p21 and 17p13 (TP53). The frequency of loss of heterozygosity (LOH) at 3p21 in pharyngeal cancers $(66.7 \%)$ was significantly higher than in oral and tongue cancers (20.0 and 14.8\%) $(\mathrm{p}=0.0006$ and 0.0003 , respectively) (Table IIIA). The frequencies of $\mathrm{LOH}$ at 3 p21 in mesopharyngeal and hypopharyngeal cancers (63.6

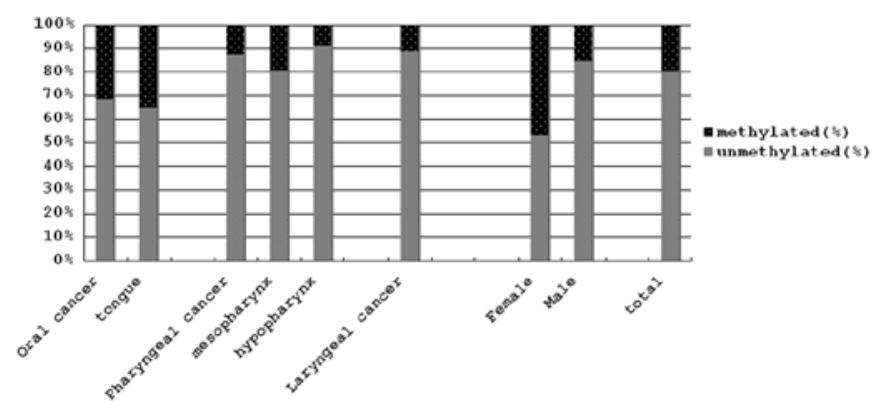

Figure 2. Hypermethylation of the p16 gene promoter region in HNSCC. The frequencies of hypermethylation of the p16 gene promoter region are shown in the percentage column for each site. Columns on the left show differences between oral cancer and cancers of the pharynx and larynx. Columns on the right show differences between females and males.

and $68.8 \%$ ) were also significantly higher than in oral cancers ( $p=0.018$ and $p=0.002$, respectively). The frequencies of $\mathrm{LOH}$ at 3 p21 in mesopharyngeal and hypopharyngeal cancers were also significantly higher than in tongue cancers $(\mathrm{p}=0.009$ and $\mathrm{p}=0.001$, respectively).

Although the frequencies of $\mathrm{LOH}$ at $9 \mathrm{p} 21$ in pharyngeal $(58.3 \%)$ and laryngeal cancers $(60.0 \%)$ were higher than in oral cancers $(34.6 \%)$, significant differences were not observed. The frequencies of $\mathrm{LOH}$ at $9 \mathrm{p} 21$ in mesopharyngeal $(44.4 \%)$ and hypopharyngeal cancers $(66.7 \%)$ were also higher than in tongue cancers $(33.3 \%)$. However, significant differences were also not observed (Table IIIB).

The frequencies of $\mathrm{LOH}$ at $17 \mathrm{p} 13$ in pharyngeal $(71.0 \%)$ and laryngeal cancers $(73.1 \%)$ were significantly higher than in oral cancers $(36.1 \%)(\mathrm{p}=0.009$ and $\mathrm{p}=0.009$, respectively). The frequencies of $\mathrm{LOH}$ at $17 \mathrm{p} 13$ in pharyngeal and laryngeal cancers were significantly higher than in tongue cancers $(37.0 \%)(p=0.02$ and $\mathrm{p}=0.018$, respectively). The frequency of $\mathrm{LOH}$ at $17 \mathrm{p} 13$ in mesopharyngeal cancers $(81.8 \%)$ was significantly higher than 
Table III. LOH at 3p21, 9p21 and TP53 and tumor location.

$\mathrm{A}, \mathrm{LOH}$ at $3 \mathrm{p} 21$ and location of tumors.

\begin{tabular}{|c|c|c|c|c|}
\hline \multirow[b]{2}{*}{ Location } & \multicolumn{4}{|c|}{$3 \mathrm{p} 21$} \\
\hline & $\mathrm{N}$ & $\mathrm{LOH}(+)$ & $\mathrm{LOH}(-)$ & P-value \\
\hline Oral cavity & 35 & 7 & 28 & $\mathrm{p}=0.018(\mathrm{MP})^{\mathrm{a}}, \mathrm{p}=0.002(\mathrm{HP})^{\mathrm{b}}$ \\
\hline Tongue & 27 & 4 & 23 & $\mathrm{p}=0.009(\mathrm{MP})^{\mathrm{c}}, \mathrm{p}=0.001(\mathrm{HP})^{\mathrm{d}}$ \\
\hline Floor of mouth & 4 & 1 & 3 & \\
\hline Buccal mucosa & 2 & 1 & 1 & \\
\hline Gingiva & 2 & 1 & 1 & \\
\hline Pharynx & 27 & 18 & 9 & $\mathrm{p}=0.0006(\mathrm{OC})^{\mathrm{e}}, \mathrm{p}=0.0003(\mathrm{~T})^{\mathrm{f}}$ \\
\hline Mesopharynx & 11 & 7 & 4 & \\
\hline Hypopharynx & 16 & 11 & 5 & \\
\hline Larynx & 28 & 12 & 16 & \\
\hline Total & 90 & 37 & 53 & \\
\hline
\end{tabular}

Significant differences were observed between a oral cavity (OC) and mesopharynx (MP), ${ }^{b} \mathrm{OC}$ and hypopharynx (HP), ${ }^{c}$ tongue (T) and MP, ${ }^{\mathrm{d}}$ tongue (T) and HP, ${ }^{\mathrm{e}} \mathrm{OC}$ and pharynx (P), $\mathrm{T}$ and P. LOH, loss of heterozygosity.

$\mathrm{B}, \mathrm{LOH}$ at $9 \mathrm{p} 21$ and location of tumors.

\begin{tabular}{lcccc}
\hline & & & $9 \mathrm{p} 21$ & P-value \\
\cline { 2 - 5 } Location & $\mathrm{N}$ & $\mathrm{LOH}(+)$ & $\mathrm{LOH}(-)$ & - \\
\hline Oral cavity & 26 & 9 & 17 & - \\
Tongue & 18 & 6 & 2 & - \\
Floor of mouth & 4 & 2 & 2 & - \\
Buccal mucosa & 3 & 1 & 0 & - \\
Gingiva & 1 & 14 & 10 & - \\
Pharynx & 24 & 4 & 5 & - \\
Mesopharynx & 9 & 10 & 10 & - \\
Hypopharynx & 15 & 15 & 37 & - \\
Larynx & 25 & 38 & & \\
Total & 75 & 15 & \\
\hline
\end{tabular}

No significant difference was observed. LOH, loss of heterozygosity.

C, LOH at TP53 and location of tumors.

\begin{tabular}{|c|c|c|c|c|}
\hline \multirow[b]{2}{*}{ Location } & \multicolumn{4}{|c|}{ TP53 } \\
\hline & $\mathrm{N}$ & $\mathrm{LOH}(+)$ & LOH(-) & P-value \\
\hline Oral cavity & 36 & 13 & 23 & $\mathrm{p}=0.02(\mathrm{MP})^{\mathrm{a}}, \mathrm{p}=0.009(\mathrm{P})^{\mathrm{b}}$ \\
\hline Tongue & 27 & 10 & 17 & $\mathrm{p}=0.03(\mathrm{MP})^{\mathrm{c}}, \mathrm{p}=0.02(\mathrm{P})^{\mathrm{d}}$ \\
\hline Floor of mouth & 4 & 1 & 3 & \\
\hline Buccal mucosa & 3 & 0 & 3 & \\
\hline Gingiva & 2 & 2 & 0 & \\
\hline Pharynx & 31 & 22 & 9 & \\
\hline Mesopharynx & 11 & 9 & 2 & \\
\hline Hypopharynx & 20 & 13 & 7 & \\
\hline Larynx & 26 & 19 & 7 & $\mathrm{p}=0.009(\mathrm{OC})^{\mathrm{e}}, \mathrm{p}=0.018(\mathrm{~T})^{\mathrm{f}}$ \\
\hline Total & 93 & 54 & 39 & \\
\hline
\end{tabular}

Significant differences were observed between ${ }^{\mathrm{a}}$ oral cavity (OC) and mesopharynx (MP), ${ }^{\mathrm{b}} \mathrm{OC}$ and pharynx (P), ${ }^{\mathrm{c}}$ tongue (T) and MP, ${ }^{\mathrm{d}} \mathrm{T}$ and $\mathrm{P}$, ${ }^{\mathrm{e}} \mathrm{OC}$ and larynx (L), ${ }^{\mathrm{f}} \mathrm{T}$ and L. LOH, loss of heterozygosity. 


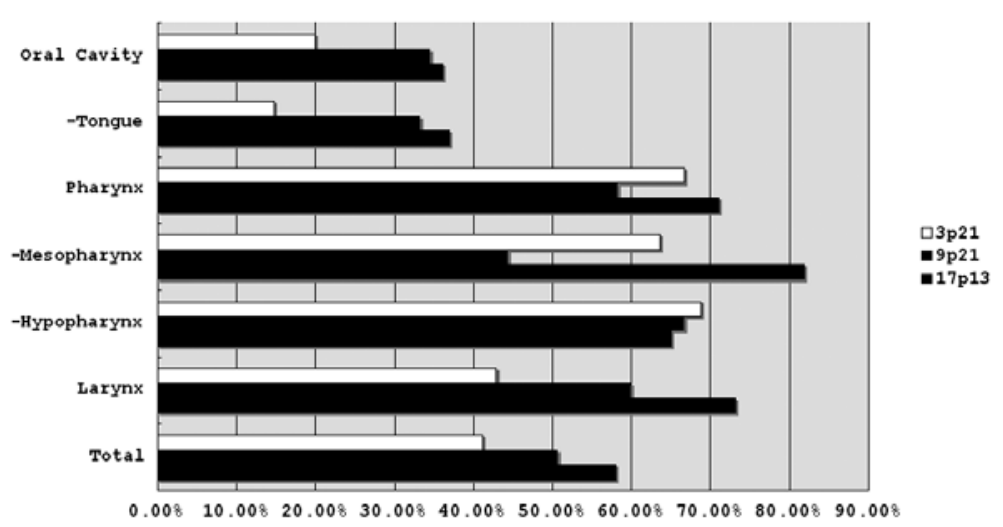

Figure 3. Differences in the frequencies of LOH in HNSCC. The frequencies of LOH are shown in the percentage column for each site. Significant differences were observed in comparison between the frequencies of $\mathrm{LOH}$ of cancers of various regions of the head and neck (Table III and relevant text). LOH, loss of heterozygosity; HNSCC, head and neck squamous cell carcinoma.

in oral and tongue cancers $(\mathrm{p}=0.02$ and $\mathrm{p}=0.03$, respectively (Table IIIC). These results are summarized in Fig. 3.

\section{Discussion}

We focused on differences in HNSCCs at various regions of origin with respect to the genetic and epigenetic aspects of the tumors. Although we have previously reported differences in the frequencies of allelic loss in several regions of head and neck cancers (10), in the present study our results indicate that there are marked differences in the frequencies of hypermethylation of genes between oral cancers and cancers of the pharynx and larynx, as well as allelic loss.

There have been numerous studies on the hypermethylation status of the promoter region of the p16 tumor suppressor gene. The frequency of methylation was found to be approximately $30 \%$ in head and neck squamous cell carcinoma specimens obtained from surgically removed tumors (1-9). Although several reports have described the hypermethylation of the promoter region of the p16 tumor suppressor gene in oral cancer and in cancers of the pharynx and larynx, there have not been any reports which point out differences in the frequencies of the methylation among those cancers. This may have been largely due to the low number of samples.

Our results indicate that the hypermethylation of the promoter region of the p16 tumor suppressor gene is related to gender, i.e., female patients tend to have more frequent hypermethylation of the p16 gene. El-Naggar et al also reported that there was no significant correlation between p16 alterations and the clinicopathological factors of the patients, with the exception of gender (3). Although their methods of characterization were different from ours and the detection of the hypermethylation itself was carried out using a method different from ours, their results are compatible with ours. Oral cancer patients included significantly more females than patients with cancers of the pharynx and larynx. We assumed that this tendency resulted in the significant differences of the frequencies of hypermethylation between oral cancer and cancers of the pharynx and larynx. This indicates that the hypermethylation of the promoter region of the p16 tumor suppressor gene may be a crucial factor in the carcinogenesis of squamous cell carcinomas of the head and neck in female patients.
In HNSCC, allelic loss on chromosome 9p occurs most frequently at $9 \mathrm{p} 21(1,13-15)$ and it occurs as an early event in the process of carcinogenesis in head and neck cancers (13). This region of 9p21 includes the tumor suppressor and cell cycle regulator gene, p16 (INK4a, also known as CDKN2 or MTS1) (16-19). Although homozygous deletions, monosomy and point mutations of p16 occur frequently in HNSCC cell lines, corresponding evidence of the same alterations in primary cancer specimens is less common $(1,14,20,21)$. However, primary HNSCC shows frequent methylation of the promoter region of the p16 gene $(22,23)$ and $\mathrm{LOH}$ at 9p21. It appears that these two types of gene alteration are the main mechanism underlying the inactivation of the p16 gene as a tumor suppressor. In our study, $\mathrm{LOH}$ at 9p21 was observed in approximately half of the specimens, and it was more frequent in cancers of the pharynx and larynx than in oral cancer. In contrast, hypermethylation of the p16 gene was more frequent in oral cancer than in cancers of the pharynx and larynx. These results indicate that the type of inactivation of the p16 gene is different in various sites of head and neck squamous cell carcinomas. It should also be noted that allelic loss at $3 p$ and $17 p$ is significantly more frequent in cancers of the pharynx and larynx than in oral cancers.

In conclusion, although these tumors were diagnosed as squamous cell carcinomas, the process of carcinogenesis may be different in tumors located in different parts of the head and neck. Loss of function of tumor suppressor genes by allelic loss is mainly active and give rise to tumors in the pharynx and larynx, while loss of function due to methylation of the promoter region of the genes is related to carcinogenesis in the oral cavity, which may place additional burden on allelic loss.

\section{Acknowledgements}

We are grateful to Ms. Elizabeth Hearing for her editorial work in the preparation of this manuscript.

\section{References}

1. Reed AL, Califano J, Cairns P, Westra WH, Jones RM, Koch W, Ahrendt S, Eby Y, Sewell D, Nawroz H, Barterk J and Sidransky D: High frequency of p16 (CDKN2/MTS-1/INK4A) inactivation in head and neck squamous cell carcinoma. Cancer Res 56: 3630-3633, 1996. 
2. Gonzalez MV,Pello MF,Lopez-Larrea C, Suarez C, Menendez MJ and Coto E: Deletion and methylation of the tumor suppressor gene p16/CDKN2 in primary head and neck squamous cell carcinoma. J Clin Pathol 50: 509-512, 1997.

3. El-Naggar AK, Lai S, Clayman G, Lee J-K J,Luna MA, Goepfert H and Batsakis JG: Methylation, a major mechanism of p16/CDKN2 gene inactivation in head and neck squamous cell carcinoma. Am J Pathol 151: 1767-1774, 1997.

4. Sanchez-Cespedes M, Esteller M, Wu L, Nawroz-Danish H, Yoo GH, Koch WM, Jen J, Herman JG and Sidransky D: Gene promoter hypermethylation in tumors and serum of head and neck cancer patients. Cancer Res 60: 892-895, 2000.

5. Hasegawa M, Nelson HH, Peters E, Ringstrom E, Posner M and Kelsey KT: Patterns of gene promoter methylation in squamous cell cancer of the head and neck. Oncogene 21: 4231-4236, 2002

6. Weber A, Wittekind C and Tannapfel A: Genetic and epigenetic alterations of 9 p21 gene products in benign and malignant tumors of the head and neck. Pathol Res Pract 199: 391-397, 2003.

7. Ai L, Stephenson KK, Ling W, Zuo C, Mukunyadzi P, Suen JY, Hanna E and Fan C-Y: The p16 (CDKN2a/INK4a) tumorsuppressor gene in head and neck squamous cell carcinoma: a promoter methylation and protein expression study in 100 cases. Mod Pathol 16: 944-950, 2003.

8. Maruya S, Issa J-PJ, Weber RS, Rosenthal DI, Haviland JC, Lotan R and El-Naggar AK: Differential methylation status of tumor-associated genes in head and neck squamous cell carcinoma: incidence and potential implications. Clin Cancer Res 10: 3825-3830, 2004.

9. Puri SK, Si L, Fan C-Y and Hanna E: Aberrant promoter hypermethylation of multiple genes in head and neck squamous cell carcinoma. Am J Otolaryngol 26: 12-17, 2005.

10. Shiga K, Matsuura K, Tateda M, Saijo S, Ogawa T, Miyagi T and Kobayashi T: Allelic loss correlated with tissue specificity in head and neck squamous cell carcinomas and the clinical features of patients. Tohoku J Exp Med 204: 163-172, 2004.

11. Shiga $\mathrm{K}$, Yamamoto $\mathrm{H}$ and Okamoto $\mathrm{H}$ : Isolation and characterization of the human homologue of rig and its pseudogenes: The functional gene has features characteristic of housekeeping genes. Proc Natl Acad Sci USA 87: 3594-3598, 1990.

12. Shiga K, Shiga C, Sasano H, Miyazaki S, Yamamoto $T$, Yamamoto M, Hayashi N, Nishihira T and Mori S: Expression of c-erbB-2 in human esophageal carcinoma cells: overexpression correlated with gene amplification or with GATA-3 transcription factor expression. Anticancer Res 13: 1293-1302, 1993.
13. Van der Riet P, Nawroz H, Hruban RH, Corio R, Tokino K, Koch W and Sidransky D: Frequent loss of chromosome 9p21-22 early in head and neck cancer progression. Cancer Res 54: $1156-1158,1994$

14. Zhang S-Y, Klein-Szanto AJP, Sauter ER, Shafarenko M, Mitsunaga S, Nobori T, Carson DA, Ridge JA and Goodrow TL: Higher frequency of alterations in the p16/CDKN2 gene in squamous cell carcinoma cell lines than in primary tumors of the head and neck: Cancer Res 54: 5050-5053, 1994.

15. Nawroz H, van der Riet P, Hruban RH, Koch W, Ruppert JM and Sidransky D: Allotype of head and neck squamous cell carcinoma. Cancer Res 54: 1152-1155, 1994.

16. Serrano M, Hannon GJ and Beach D: A new regulatory motif in cell cycle control causing specific inhibition of cyclin D/CDK4. Nature 366: 704-707, 1993.

17. Serrano M, Lee H-W, Chin L, Cordon-Cardo C, Beach D and Depinho RA: Role of the INK4a locus in tumor suppression and cell mortality. Cell 85: 27-37, 1996.

18. Kamb A, Gruis NA, Weaver-Fejdhaus J, Lin Q, Harshman K, Tavtigian SV, Stockert E, Day III RS, Johnson BE and Skolnick MH: A cell cycle regulator potentially involved in genesis of many tumor types. Science 264: 436-440, 1994.

19. Sherr CJ: Cancer cell cycles. Science 274: 1672-1677, 1996.

20. Cairns P, Polascik TJ, Eby Y, Tokino K, Califano J, Merlo A, Mao L, Herath J, Jenkins R, Westra W, et al: Frequency of homozygous deletion at p16/CDK2 in primary human tumors. Nat Genet 11: 210-212, 1995 .

21. Lydiatt WM, Murty VV, Davidson BJ, Xu L, Dyomina K, Sacks PG, Schantz SP and Chaganti RS: Homozygous deletions and loss of expression of the CDKN2 gene occur frequently in head and neck squamous cell carcinoma cell lines but infrequently in primary tumors. Genes Chromosomes Cancer 13: 94-98, 1995 .

22. Herman JG, Merlo A, Mao L, Lapidus RG, Issa J-PJ, Davidson NE, Sidransky D and Baylin SB: Inactivation of the CDKN2/p16/MTS1 gene is frequently associated with aberrant DNA methylation in all common human cancers. Cancer Res 55: 4525-4530, 1995.

23. Merlo A, Herman JG, Mao L, Lee DJ, Gabrielson E, Burger PC, Baylin SB and Sidransky D: 5' CpG island methylation is associated with transcriptional silencing of the tumor suppressor p16/CDKN2/MTS1 in human cancers. Nat Med 1: 686-692, 1995. 